\title{
Does soft skill development vary among the students? A gender perspective
}

\author{
Md. Roknuzzaman Siddiky
}

Noakhali Science and Technology University, Department of Sociology, Noakhali-3814, Bangladesh, rokonsiddiky@hotmail.com

ABSTRACT The study was intended to examine the extent to which soft skill development varied among the university students by gender via their participation in co-curricular activities (CCAs). Moreover, the study aimed to find out whether there was a significant difference between male and female students concerning soft skill development. The study has shown that males have developed diverse personal skills and social skills, that is, soft skills more than females excepting one which is presentation skill. The study has pointed out that soft skill development significantly varies among the students by gender excepting presentation skill development. The study has proposed that the significant difference between male and female students regarding soft skill development may be attributed to their difference in participating in various CCAs. Since the males are more likely to participate in CCAs, they are more likely to develop diverse soft skills than the females. The study has indicated that Muslim female students face several personal and social barriers including lack of confidence, conservative family values, and people's negative attitudes to participate in CCAs, which requires proper policy to address.

Keywords: $\quad$ Co-curricular activities, Personal skills, Social skills, Soft skills, Soft skill development 


\section{INTRODUCTION}

Co-curricular activities (CCAs) refer to those activities and programs that complement the curricular or main syllabus activities in educational institutions. They are organized in order to help the students to gain a better understanding of the course and facilitate their different skill development tasks (Dhanmeher, 2014; Ingale, 2014; Siddiky, 2019). A number of studies have proposed that CCAs have effects on the development of personality and diverse soft skills of the students (Brandfon, 2018; Daniyal, Nawaz, Hassan, \& Mubeen, 2012; Dhanmeher, 2014; Ismail et al., 2016; Ivaniushina \& Zapletina, 2015; Ivanova, Martins, \& Kaftasev, 2017; Kumar \& Selvaraju, 2014; Jamal, 2012; Le, 2013; Mehmood, Hussain, Khalid, \& Azam, 2012; Nghia, 2017; Prianto, 2016; Siddiky, 2019; Singh \& Mishra, 2015; Villalobos et al., 2016). These activities are very important parts of educational institutions to develop the students' personality, morality, integrity and ethics, and strengthen the classroom learning (Ingale, 2014). CCAs are usually designed to focus on the enhancement of the students' intellectual capability, physical and mental fitness, analytical ability, and development of their leadership quality and interpersonal communication skills. CCAs also concentrate on the students' engagement in diverse social networks (Bartkus, Nemelka, Nemelka, \& Gardner, 2012; Daniyal et al., 2012; Dhanmeher, 2014; Kumar \& Selvaraju, 2014; Leung, Ng, \& Chan, 2011; Mehmood et al., 2012; Siddiky, 2019). This is noteworthy that CCAs and ECAs (broadly known as extracurricular activities) are the two words often used interchangeably across the world (Leung et al., 2011; Lunenburg, 2010; Singh \& Mishra, 2015 ). At present, there is no precise distinction between these two types of activities since many of such activities may overlap each other. Most of the schools or universities across the world do not generally make a distinction between CCAs and ECAs since these two sorts of activities are of equal value to facilitate soft skill development of the students (Siddiky, 2019).

Numerous studies are available in the academic world pertaining to the effects of CCAs and ECAs on the students' behavioural and personality patterns and diverse skills. The studies have put forward that CCAs or ECAs have positive association with the students' personality formation and soft skill development. Mehmood et al. (2012) found that the CCAs have significant relationship with the development of some selected personality traits involving self-confidence, honesty, adaptation, sociability, sympathetic attitude, social obligation and sense of responsibility among secondary school students. They also observed that CCAs have stronger impact on the development of such personality traits among male secondary school students than female secondary school students. Daniyal et al. (2012) put forward that the CCAs, especially athletic and sports improve the academic performance of the students. Jamal (2012) suggested that the participation in the ECAs promotes the interpersonal skills and professional behaviours of the medical students of the King Abdulaziz University in Jeddah. Le (2013) found that there is statistically a significant association between participation in ECAs and less engagement in risky behaviours among the Australian adolescents while the effects vary in terms of type of activity, gender, and partly by socio-economic status.

Dhanmeher (2014) found that CCAs have stronger relationship with the development of diverse personality qualities including adaptation, self-confidence, honesty, sociability, sympathetic attitude, social obligation, sense of responsibility, time management and leadership qualities among Junior College Students. Hayes (2014) observed that the students' participation in school-based ECAs has enhanced their 12 perceived skills and such skills are transferrable to other areas of their lives including school, work, and/or home. Kumar and Selvaraju (2014) indicated that the students' participation in CCAs have contributed to their personality development based on seven dimensions that involve appearance, verbal mannerism, gesticulation, mental alertness, stability of thoughts, leadership skills and self-confidence. They observed that there is no significant difference between males and females in their participation in CCAs overall. While there is a significant difference between male and female students in their personality development relating to three dimensions, there is no significant difference between them concerning personality development overall. 
Ivaniushina and Zapletina (2015) opined that the ECAs have a positive impact on the development of personality and interpersonal skills. They found that the ECAs have helped to develop many personal and social skills of Russian students. Each kind of the selected ECAs has different effects on the development of the competencies and interpersonal skills of the students. Singh and Mishra (2015) observed that the ECAs, especially,yoga, horse riding, sport activities, dance, and music have significant association with the student's performance in the government and private schools. They found that the benefits of participating in the ECAs involved having better grades, having higher standardized test scores and higher educational attainment, attending school more regularly, and having a higher selfconcept. Ismail et al. (2016) propounded that the ECAs have a positive impact on the development of personality traits of the students of different universities in Pakistan. Villalobos et al. (2016) found that the CCAs have contributed to the development of the relationship skills of the Pilipino financial and management accounting students, and allow them to manage their time effectively and enhance their academic performance.

Prianto (2016) suggested that the more intensively the college graduates are involved in ECAs, the better the quality of soft skills and readiness to work they have. Ivanova et al. (2017) revealed that the students who are involved in ECAs are more likely to develop their level of soft skills than that of the students who are not involved in such activities. Nghia (2017) asserted that students' participation in ECAs has developed their generic skills involving communication skills, creative thinking skills, presentation skills and teamwork skills in some Vietnamese universities. Brandfon (2018) suggested that the students who are involved in CCAs in college, are more likely to gain important leadership skills and competencies, and are more likely to gain skills deemed important by employers and necessary for job success. Siddiky (2019) found that the undergraduate students of a public university of Bangladesh have developed a wide range of personal and social skills including communication skill, organizing skill, presentation skill, public speaking skill and analytical skill through their participation in diverse CCAs. His study also claimed that involvement in CCAs could develop a sense of social responsibility among the students and allow them to work for humanity or society. CCAs have also effect on socializing the students (Siddiky, 2019). Hence, it may be argued that the students' participation in CCAs is positively associated with their soft skill development. While CCAs or ECAs contribute to soft skill development of the students by cultivating their diverse personal and social skills, the empirical studies available in the academic world whether soft skill development varies among the students by gender are not adequate so that proper policy can be made.

As such, the purpose of the study is to find out the extent to which soft skill development varies among the students by gender via their participation in diverse CCAs. The study also aims to explore whether there is statistically a significant difference between male and female students concerning their soft skill development. The study has set four research questions pertaining to its purpose. In this regard, the study has sought to investigate several queries corresponding to research questions as shown in Table 1.

Table1.

Research questions and queries

\begin{tabular}{|c|c|c|}
\hline No. & Research Questions & Specific Queries \\
\hline 1 & $\begin{array}{l}\text { Does the students' participation in CCAs vary } \\
\text { in terms of gender? }\end{array}$ & $\begin{array}{l}\text { To investigate the extent to which the students' participation in } \\
\text { CCAs varies in terms of gender } \\
\text { To find out the significance of difference between male and } \\
\text { female students in their participation in CCAs }\end{array}$ \\
\hline 2 & $\begin{array}{l}\text { Does soft skill development vary among the } \\
\text { students by gender? }\end{array}$ & $\begin{array}{l}\text { To find out the extent to which the development of personal } \\
\text { skills varies among the students by gender } \\
\text { To find out the extent to which the development of social skills } \\
\text { varies among the students by gender }\end{array}$ \\
\hline 3 & $\begin{array}{l}\text { Does soft skill development vary significantly } \\
\text { among the students by gender? }\end{array}$ & $\begin{array}{l}\text { To investigate whether personal skill development varies } \\
\text { significantly among the students by gender } \\
\text { To find out whether social skill development varies significantly } \\
\text { among the students by gender }\end{array}$ \\
\hline 4 & $\begin{array}{l}\text { What are the barriers faced by female students } \\
\text { to participate in CCAs? }\end{array}$ & $\begin{array}{l}\text { To find out the personal and social barriers faced by Muslim } \\
\text { female students to participate in CCAs }\end{array}$ \\
\hline
\end{tabular}




\section{Conceptual Framework of Soft Skill Development}

Human skills may be categorized into two types - hard skills and soft skills. Hard skills are those specific skills or capacities which are required to perform a particular job while soft skills combine a set of skills or capacities that persons usually learn through their observations, practices, experiences and interaction with other people (Babic \& Slavkovic, 2011; Cimatti, 2016; Patacsil \&Tablatin, 2017). In contrast to hard skills, soft skills are not directly connected to a particular job and are known to be such personal attributes and social competences that include language and communication skill, leadership skill, presentation skill, friendliness, and ability to work in team and other personality traits that characterize the relationships between people (Cimatti, 2016; Cornalli, 2018). Hence, soft skills combine both personal skills and social skills (Cimatti, 2016). Personal skills may incorporate the level of knowledge acquisition, creative thinking skill, presentation skill, punctuality, self-motivation, language skill, analytical skill and so on. However, social skills are those skills, which are usually used in every environment involving two or more people (Learning Disabilities Association of Canada [LDAC], n.d.). Put differently, social skills are such skills that persons use to communicate or interact with each other. Hence, social skills may involve communication skill, leadership skill, organizing skill, friendliness, adaptability, social responsibility, network-building skill, extroversion, and so on (Chua, Chuatoco, Dela Pena, Jimenez, \& Co, 2017; Cimatti, 2016; National Association of School Psychologists [NASP], 2002; Prianto, 2016; Villalobos et al., 2016). Thus, Cimatti (2016) put forward that personal skills mainly involve cognitive skills including knowledge and thinking skills while social skills are concerned with relationships with other people. However, this is to note that personal and social skills cannot be differentiated properly since many of such skills may overlap each other. Numerous studies pointed out that the students' participation in various CCAs or ECAs, lead to the development of their diverse personal and social skills, that is, soft skill development (Brandfon, 2018; Chua et al., 2017; Dhanmeher, 2014; Ivaniushina \& Zapletina, 2015; Nghia, 2017; Prianto, 2016; Villalobos et al., 2016). In the light of previously mentioned discussion, the study represents a conceptual framework of soft skill development by gender, which is illustrated in Figure 1.

As shown below in Figure 1, students' participation in CCAs by gender may contribute to their variation in personal skill development by facilitating a number of skills and personality traits associated with personal skills. In view of aforesaid conceptual definition, personal skill development may be measured in terms of eight dimensions or indicators which include the level of knowledge acquisition, creativethinking skill, presentation skill, punctuality, self-motivation skill, language skill, analytical skill, and problem-solving skill. Similarly, students' participation in CCAs by gender may contribute to their variation in social skill development by cultivating diverse skills and personality traits related to social skills. Social skill development may be measured in terms of nine dimensions, which involve leadership skill, communication skill, organizing skill, network-building skill, and adaptation skill, and friendliness, sense of social responsibility, teamwork-building skill, and finally extroversion.

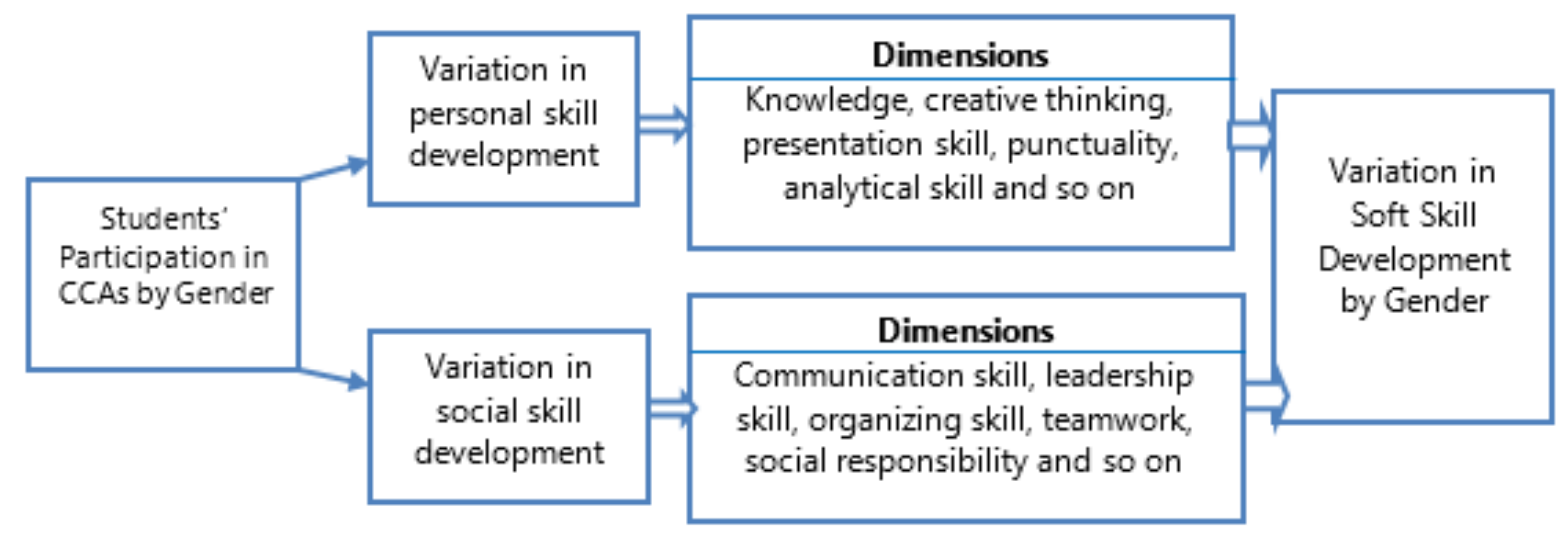

Figure1.Conceptual framework of soft skill development by gender 
As such, the volume of students' participation in diverse CCAs by gender might result in variation in personal skill development and social skill development and thereby contribute to the variation in soft skill development among the students by gender. Based on this conceptual model, the study has attempted to find out whether soft skill development varies among the students by gender. Moreover, the study has sought to explore whether there is a significant difference between male and female students concerning their soft skill development. The study has viewed gender as an independent variable while corresponding dimensions of personal skill development and social skill development as dependent variables.

\section{Rationale of the Study}

Ensuring Quality education has been viewed not only as an essential part of Sustainable Development Goals (SDGs) but also as a key to promoting lifelong learning opportunities for all (Educate A Child, 2016; United Nations Educational, Scientific and Cultural Organization [UNESCO], 2017a, 2017b). Hence, quality education is one of the priority-areas in the SDGs to promote the development of human capabilities so that they could contribute to the achievement of SDGs in order to make a sustainable, prosperous and equitable planet (Lane, 2017; UNESCO, 2017a). To make sure quality education in the public universities of Bangladesh, it is very important to facilitate soft skill development of the students through organizing diverse CCAs or ECAs. While CCAs could foster soft skill development of the students, there has not been so far sufficient volume of comprehensive empirical studies in the academia, especially in Bangladesh perspective to find out the extent to which soft skill development varies among the students by gender. In other words, the availability of studies as to whether there is any significant difference between male and female students with respect to their soft skill development is far from satisfactory. Moreover, no study has been conducted so far in Bangladesh context to identify the personal and social barriers for females, especially for Muslim female students to participate in CCAs. Hence, the present study would fill-up the knowledge gap by examining such difference among the students by gender and identifying the barriers that restrict female students from their participation in CCAs. The study would help the researchers to supplement their knowledge and support the policy makers and educationists to formulate proper policy concerning soft skill development. Therefore, the present study caries much significance not only from academic point of view but also from policy perspective.

\section{METHODOLOGY}

\section{Type of Study and Ethical Issues}

The study was a survey research. While the study was primarily a quantitative, it took into account both approaches, that is, quantitative and qualitative approaches to have a deeper understanding of the fact. Quantitative approach was applied to find out the extent to which soft skill development varies among the students by gender while qualitative approach was employed so as to investigate the underlying barriers to females' participation in CCAs from the point of view of the female respondents. Before conducting the survey, all the participants were duly informed of the purpose of the study. They participated in this research voluntarily. The researcher did not have any sort of financial dealings with the respondents. The researcher maintained honesty and confidentiality throughout his research work. In this regard, this is to mention that the Office of Research Cell of Noakhali Science and Technology University issued an ethical approval certificate for the honesty and sincerity of the researcher during data collection procedure.

\section{The Study Group}

The study was a survey research. While the study was primarily a quantitative, it took into account both approaches, that is, quantitative and qualitative approaches to have a deeper understanding of the fact. Quantitative approach was applied to find out the extent to which soft skill development varied among the students by gender while qualitative approach was employed so as to investigate the underlying 
barriers, especially personal and social barriers to females' participation in CCAs from the point of view of the female respondents. Before conducting the survey, all the participants were duly informed of the purpose of the study. They participated in this research voluntarily. The researcher did not have any sort of financial dealings with the respondents. The researcher maintained honesty and confidentiality throughout his research work. In this regard, this is to mention that the Office of Research Cell of Noakhali Science and Technology University issued an ethical approval certificate for the honesty and sincerity of the researcher during data collection procedure.

\section{Sampling and Data Collection}

A total of 152 samples were selected by using judgmental and snowball sampling techniques, types of non-probability sampling procedure, from the undergraduate and master's students of 16 academic departments due to the unavailability of sampling frame and convenience of the researcher. The primary data for this research project were collected from a sample survey by using a structured questionnaire administered by the researcher and his team consisting of his six undergraduate students. Moreover, qualitative interviews were carried out with purposively chosen five Muslim female respondents in order to identify the personal and social barriers that the Muslim female students faced to participate in CCAs. Since most of the female respondents were Muslim, the researcher deliberately categorized five female respondents based on their status of wearing Hijab. Of them, two were wearing Hijab and the rest were not. The reason for employing qualitative interviews with Muslim female respondents was to examine their personal views or understandings about their impediments to participate in CCAs. The survey was conducted from August 2019 to October 2019.

\section{Data Analysis Procedure}

The quantitative data were analyzed by using both descriptive and inferential statistics. 5-point Likert type scales were used to measure the degree of soft skill development and investigate the extent to which soft skill development varied among the respondents by gender. The study reasonably used median values rather than mean values because of the ordinal character of data (Nachmias \& Nachmias, 2008). Since the samples were not randomly drawn from a normally distributed population and the ordinal nature of data, the parametric t-test was not appropriate statistical test to find out the significant difference between male and females students concerning their soft skill development (Corder \& Foreman, 2009). As such, the study employed the Mann-Whitney U-test to find out whether soft skill development varied significantly among the students by gender, that is, to explore whether there was any significance of difference between male and female students with respect to their soft skill development. All sorts of statistical analysis were carried out by using SPSS software. The Cronbach's alpha was carried out in order to find out the reliability or internal consistency of the items of the measurement. The Cronbach's alpha Coefficient was .960 (greater than .70) which indicated that the items of scales in the measurement were reliable (Taber, 2017). Qualitative data were analyzed and interpreted by means of making comparison, finding themes or underlying meanings of the concepts, and investigating their relationship.

\section{FINDINGS}

Table 2 presented below shows the descriptive statistics of the respondents' characteristics. Specifically, the Table describes the classification of statistical data on the basis of the respondents' characteristics with regard to six variables-department, gender, academic year, age, major CCAs participated by the respondents, and distribution of major CCAs by gender. 
Table 2.

Descriptive statistics of the respondents' characteristics

\begin{tabular}{|c|c|c|c|c|}
\hline Variables & & Frequency & Percent & \\
\hline \multirow{17}{*}{ Department } & ACCE & 8 & 5.3 & \\
\hline & BLWS & 19 & 12.5 & \\
\hline & CSTE & 7 & 4.6 & \\
\hline & DBA & 9 & 5.9 & \\
\hline & $\mathrm{ECO}$ & 6 & 3.9 & \\
\hline & EDU & 6 & 3.9 & \\
\hline & ENG & 12 & 7.9 & \\
\hline & ESDM & 13 & 8.6 & \\
\hline & FIMS & 7 & 4.6 & \\
\hline & FTNS & 7 & 4.6 & \\
\hline & ISLM & 6 & 3.9 & \\
\hline & Micro & 7 & 4.6 & \\
\hline & MIS & 15 & 9.9 & \\
\hline & SOC & 17 & 11.2 & \\
\hline & STAT & 6 & 3.9 & \\
\hline & THM & 7 & 4.6 & \\
\hline & Total & 152 & 100.0 & \\
\hline \multirow{3}{*}{ Gender } & Male & 89 & 58.6 & \\
\hline & Female & 63 & 41.4 & \\
\hline & Total & 152 & 100.0 & \\
\hline \multirow{6}{*}{ Academic Year } & $1 \mathrm{Y}$ & 9 & 5.9 & \\
\hline & $2 \mathrm{Y}$ & 97 & 63.8 & \\
\hline & $3 \mathrm{Y}$ & 21 & 13.8 & \\
\hline & $4 Y$ & 13 & 8.6 & \\
\hline & 5Y(Masters) & 12 & 7.9 & \\
\hline & Total & 152 & 100.0 & \\
\hline \multirow{6}{*}{ Major CCAs participated by the respondents } & Sports & 29 & 19.1 & \\
\hline & Cultural programs & 65 & 42.8 & \\
\hline & Debating & 24 & 15.8 & \\
\hline & MUN programs & 19 & 12.5 & \\
\hline & Others & 15 & 9.9 & \\
\hline & Total & 152 & 100.0 & \\
\hline \multirow{7}{*}{ Distribution of major CCAs by gender } & & Male $(\%)$ & Female $(\%)$ & Total \\
\hline & Sports & 18.4 & 0.7 & 19.1 \\
\hline & Cultural programs & 17.8 & 25.0 & 42.8 \\
\hline & Debating & 7.9 & 7.9 & 15.8 \\
\hline & MUN programs & 7.2 & 5.3 & 12.5 \\
\hline & Others & 7.2 & 2.6 & 9.8 \\
\hline & Total & 58.6 & 41.4 & 100.0 \\
\hline \multirow{3}{*}{ Age } & & Mean & SD & \\
\hline & Male & 21.92 & 1.583 & \\
\hline & Female & 21.13 & 1.301 & \\
\hline
\end{tabular}

It is observed that the Bangladesh and Liberation War Studies (BLWS) Department has the highest share of the respondents (12.5\%) followed by the Sociology (SOC) Department (11.2\%), the Management Information System (MIS) Department (around 10\%), the Environmental Science and Disaster Management (ESDM) Department (8.6\% ), the English (ENG) Department (about 8\%), the Business Administration (DBA) Department (about 6\%), and the Applied Chemistry and Chemical Engineering (ACCE) Department (5.3\%). However, the Computer Science and Telecommunication Engineering (CSTE) Department, the Tourism and Hospitality Management (THM) Department, the Fisheries and Marine Science (FIMS) Department, the Microbiology (Micro) Department, and the Food Technology and Nutrition Science (FTNS) Department each shares $4.6 \%$ of the respondents. In contrast, the Economics (ECO) Department, the Statistics (STAT) Department, and the Education (EDU) Department each shares about $4 \%$ of the respondents. With regard to gender, $58.6 \%$ of the respondents 
are males while about $41.4 \%$ of the respondents are females. A great majority of the respondents belong to the $2^{\text {nd }}$ year (about $64 \%$ ) of the undergraduate programs, followed by the $3^{\text {rd }}$ year (around $14 \%$ ), $4^{\text {th }}$ year $(8.6 \%)$, Masters (roughly $8 \%$ ), and $1^{\text {st }}$ year (about 6\%). This is evident that the mean age of the male students is 21.92 years while the mean age of the female students is 21.13 years. A majority of the respondents (about 43\%) supported cultural programs for their participation in CCAs, followed by sports (around 19\%), debating (roughly 16\%), Model United Nations' or MUN programs (12.5\%), and finally others (about 10\%). The study found that among the respondents who put their opinions in favor of cultural programs for their participation in CCAs, $25 \%$ were females whereas about $18 \%$ were males. Among the respondents who put their opinions in favor of sports, about $18.4 \%$ were males while the rest $(0.7 \%)$ were females. Therefore, the study put forward that sports are more favorite to males while cultural programs are more favorite to females. Among the respondents who gave their opinions in favor of debating as their main CCAs, both males and females have the equal share ( $7.9 \%$ each). Among the respondents who put their opinions in favor of MUN programs as their main CCAs to take part, 7.2\% were males while $5.3 \%$ were females.

Table 3 shown below addresses the research question 1, that is, whether there is any difference between male and female respondents with respect to their participation in CCAs.

Table 3.

Respondents' participation in CCAs by gender

\begin{tabular}{llllllr}
\hline Type of Respondent & Median & SD & Statistical Test & Sum of Ranks & Z & $p$-value \\
\hline Male & 4.00 & .611 & \multirow{2}{*}{ Mann-Whitney $U$} & 7905.50 & \multirow{2}{*}{-4.552} & \multirow{2}{*}{.000} \\
Female & 3.00 & .613 & & & & \\
Note: $1=$ never; $2=$ rarely; $3=$ occasionally; $4=$ regularly; $5=$ very often & & & &
\end{tabular}

It is evident that the males regularly participate in CCAs (median value $=4.00$ ) whereas the females occasionally participate in CCAs (median value $=3.00$ ). The study found that there is a significant difference between male and female students with regard to their participation in CCAs since the $p$ value (.000) is less than the alpha value of 0.05 . Hence, the study put forward that the males are more likely to participate in CCAs than the females.

Table 4 presented below deals with the research question 2, especially whether personal skill development varies among the students by gender. In other words, Table 4 focuses on the extent to which personal skill development varies among the students by gender.

Table 4.

Evaluation summary of personal skill development by gender

\begin{tabular}{|c|c|c|c|c|c|c|}
\hline No. & Measurement Instruments/Indicators & $\begin{array}{c}\text { Type of } \\
\text { Respondent }\end{array}$ & Median & SD & $\begin{array}{l}\text { Highest } \\
\text { Value }\end{array}$ & Rating \\
\hline \multirow{2}{*}{1} & The extent to which level of knowledge & Male & 4.00 & .646 & \multirow{2}{*}{5.00} & Much \\
\hline & has developed & Female & 3.00 & .714 & & Moderately \\
\hline \multirow{2}{*}{2} & The extent to which creative thinking skill & Male & 4.00 & .721 & \multirow{2}{*}{5.00} & Much \\
\hline & has developed & Female & 3.00 & 689 & & Moderately \\
\hline \multirow{2}{*}{3} & The extent to which presentation skill has & Male & 4.00 & .820 & \multirow{2}{*}{5.00} & Much \\
\hline & developed & Female & 4.00 & .777 & & Much \\
\hline \multirow{2}{*}{4} & The extent to which punctuality has & Male & 4.00 & .760 & \multirow{2}{*}{5.00} & Much \\
\hline & developed & Female & 3.00 & .821 & & Moderately \\
\hline \multirow{2}{*}{5} & The extent to which self-motivational skill & Male & 4.00 & .724 & \multirow{2}{*}{5.00} & Much \\
\hline & developed & Female & 3.00 & .737 & & Moderately \\
\hline \multirow{2}{*}{6} & The extent to which language skill has & Male & 4.00 & .686 & \multirow{2}{*}{5.00} & Much \\
\hline & developed & Female & 3.00 & .733 & & Moderately \\
\hline \multirow[b]{2}{*}{7} & The extent to which analytical skill has & Male & 4.00 & .722 & \multirow{2}{*}{5.00} & Much \\
\hline & developed & Female & 3.00 & .634 & & Moderately \\
\hline \multirow{2}{*}{8} & The extent to which problem-solving skill & Male & 4.00 & .705 & \multirow{2}{*}{5.00} & Much \\
\hline & has developed & Female & 3.00 & .733 & & Moderately \\
\hline
\end{tabular}

Note: $1=$ not at all; $2=$ not; $3=$ moderately; $4=$ much; $5=$ very much 
The study found that with regard to knowledge development, the median value for male respondents is 4.00 while the median value for female respondents is 3.00. As such, the study argued that knowledge has much developed among males while it has moderately developed among females. Creative-thinking skill has much developed among males since their median value is 4.00 while it has moderately developed among females since their median value is 3.00. The study found that both males and females have developed much their presentation skill since the median value for both is 4.00 . Punctuality has much developed among males (median value $=4.00$ ) whereas such skill has moderately developed among females (median value $=3.00$ ). Self-motivational skill has much developed among males (median value $=4.00$ ) whereas such skill has moderately developed among females (median value $=$ 3.00). Language skill has much developed among males (median value $=4.00$ ) whereas such skill has moderately developed among females (median value $=3.00$ ). Analytical skill has much developed among males since their median value is 4.00 while it has moderately developed among females since their median value is 3.00. Finally, problem-solving skill has much developed among males (median value $=4.00$ ) whereas such skill has moderately developed among females (median value $=3.00$ ).

Table 5 presented below deals with the research question 2, specifically whether social skill development varies among the students by gender. Put differently, the Table explains the extent to which social skill development varies among the students by gender.

Table 5 .

Evaluation summary of social skill development by gender

\begin{tabular}{|c|c|c|c|c|c|c|}
\hline No. & Measurement Instruments/Indicators & $\begin{array}{c}\text { Type of } \\
\text { Respondent }\end{array}$ & Median & SD & $\begin{array}{l}\text { Highest } \\
\text { Value }\end{array}$ & Rating \\
\hline \multirow{2}{*}{1} & The extent to which leadership skill has & Male & 4.00 & .724 & \multirow{2}{*}{5.00} & Much \\
\hline & developed & Female & 3.00 & .873 & & Moderately \\
\hline \multirow{2}{*}{2} & The extent to which communication skill has & Male & 4.00 & .752 & \multirow{2}{*}{5.00} & Much \\
\hline & developed & Female & 3.00 & .799 & & Moderately \\
\hline \multirow{2}{*}{3} & The extent to which organizing skill has & Male & 4.00 & 692 & \multirow{2}{*}{5.00} & Much \\
\hline & developed & Female & 3.00 & .801 & & Moderately \\
\hline \multirow{2}{*}{4} & The extent to which network-building skill has & Male & 4.00 & .711 & \multirow{2}{*}{5.00} & Much \\
\hline & developed & Female & 3.00 & .840 & & Moderately \\
\hline \multirow{2}{*}{5} & The extent to which sense of social & Male & 4.00 & .775 & \multirow{2}{*}{5.00} & Much \\
\hline & responsibility has developed & Female & 3.00 & .736 & & Moderately \\
\hline \multirow{2}{*}{6} & The extent to which adaptation skill has & Male & 4.00 & .776 & \multirow{2}{*}{5.00} & Much \\
\hline & developed & Female & 3.00 & .814 & & Moderately \\
\hline \multirow{2}{*}{7} & The extent to which friendliness has & Male & 4.00 & .733 & \multirow{2}{*}{5.00} & Much \\
\hline & developed & Female & 3.00 & .710 & & Moderately \\
\hline \multirow{2}{*}{8} & The extent to which teamwork-building skill & Male & 4.00 & 675 & \multirow{2}{*}{5.00} & Much \\
\hline & has developed & Female & 3.00 & .756 & & Moderately \\
\hline \multirow{2}{*}{9} & The extent to which extroversion has & Male & 4.00 & .763 & \multirow{2}{*}{5.00} & Much \\
\hline & developed & Female & 3.00 & .854 & & Moderately \\
\hline
\end{tabular}

Note: $1=$ not at all; $2=$ not; $3=$ moderately; $4=$ much; $5=$ very much

As shown above in Table 5, with regard to leadership skill development, the median value for male students is 4.00 while the median value for female students is 3.00 . As such, the study has argued that leadership skill has much developed among males while it has moderately developed among females. Communication skill has much developed among males since their median value is 4.00 while it has moderately developed among females since their median value is 3.00. Similarly organizing skill has much developed among males while it has moderately developed among females since the median values for males and females are 4.00 and 3.00 respectively. Network-building skill has much developed among males (median value $=4.00$ ) whereas such skill has moderately developed among females (median value $=3.00$ ). Sense of social responsibility has much developed among males (median value $=4.00$ ) whereas such skill has moderately developed among females (median value $=3.00$ ). Adaptation skill has much developed among males (median value $=4.00$ ) whereas such skill has moderately developed among females (median value $=3.00$ ). Friendliness skill has much developed among males since their median value is 4.00 while it has moderately developed among females since their median 
value is 3.00. Teamwork-building skill has much developed among males (median value $=4.00$ ) whereas such skill has moderately developed among females (median value $=3.00$ ). Finally, the study has found that extroversion has much developed among males since their median value is 4.00 while it has moderately developed among females since the median value for them is 3.00 .

Table 6 is concerned with the research question 3, especially whether personal skill development significantly varies among the students by gender. In other words, the Table focuses on whether there is a significant difference between male and female students pertaining to personal skill development. In this regard, the study has tried to validate eight research hypotheses concerning personal skill development by gender, which are as follows:

Table 6.

Hypotheses testing results summary (personal skill development by gender)

\begin{tabular}{|c|c|c|c|c|c|c|c|}
\hline No. & Research hypotheses $\left(\mathrm{H}_{\mathrm{a}}\right)$ & $\begin{array}{c}\text { Statistical } \\
\text { Test }\end{array}$ & $\begin{array}{c}\text { Type of } \\
\text { Respondent }\end{array}$ & $\begin{array}{l}\text { Mean } \\
\text { Rank }\end{array}$ & $\mathrm{Z}$ & $\begin{array}{l}\text { Alpha- } \\
\text { value }\end{array}$ & $\begin{array}{c}p- \\
\text { value }\end{array}$ \\
\hline 1 & $\begin{array}{l}\text { Knowledge development varies } \\
\text { among the students by gender }\end{array}$ & $\begin{array}{l}\text { Mann- } \\
\text { Whitney } U\end{array}$ & $\begin{array}{l}\text { Male } \\
\text { Female }\end{array}$ & $\begin{array}{l}91.34 \\
55.54\end{array}$ & -5.354 & 0.05 & .000 \\
\hline 2 & $\begin{array}{l}\text { Creative-thinking skill development } \\
\text { varies among the students by gender }\end{array}$ & $\begin{array}{l}\text { Mann- } \\
\text { Whitney } U\end{array}$ & $\begin{array}{l}\text { Male } \\
\text { Female }\end{array}$ & $\begin{array}{l}86.56 \\
62.59\end{array}$ & -3.659 & 0.05 & .000 \\
\hline 3 & $\begin{array}{l}\text { Presentation skill development varies } \\
\text { among the students by gender** }\end{array}$ & $\begin{array}{l}\text { Mann- } \\
\text { Whitney } U\end{array}$ & $\begin{array}{l}\text { Male } \\
\text { Female }\end{array}$ & $\begin{array}{l}78.79 \\
73.26\end{array}$ & -.824 & 0.05 & .410 \\
\hline 4 & $\begin{array}{l}\text { Punctuality development varies } \\
\text { among the students by gender }\end{array}$ & $\begin{array}{l}\text { Mann- } \\
\text { Whitney } U\end{array}$ & $\begin{array}{l}\text { Male } \\
\text { Female }\end{array}$ & $\begin{array}{l}86.72 \\
62.06\end{array}$ & -3.658 & 0.05 & .000 \\
\hline 5 & $\begin{array}{l}\text { Self-motivational skill development } \\
\text { varies among the students by gender }\end{array}$ & $\begin{array}{l}\text { Mann- } \\
\text { Whitney } U\end{array}$ & $\begin{array}{l}\text { Male } \\
\text { Female }\end{array}$ & $\begin{array}{l}86.82 \\
61.92\end{array}$ & -3.705 & 0.05 & .000 \\
\hline 6 & $\begin{array}{l}\text { Language skill development varies } \\
\text { among the students by gender* }\end{array}$ & $\begin{array}{l}\text { Mann- } \\
\text { Whitney } U\end{array}$ & $\begin{array}{l}\text { Male } \\
\text { Female }\end{array}$ & $\begin{array}{l}81.98 \\
68.76\end{array}$ & -2.014 & 0.05 & .044 \\
\hline 7 & $\begin{array}{l}\text { Analytical skill development varies } \\
\text { among the students by gender* }\end{array}$ & $\begin{array}{l}\text { Mann- } \\
\text { Whitney } U\end{array}$ & $\begin{array}{l}\text { Male } \\
\text { Female }\end{array}$ & $\begin{array}{l}88.21 \\
59.96\end{array}$ & -4.297 & 0.05 & .000 \\
\hline 8 & $\begin{array}{l}\text { Problem-solving skill development } \\
\text { varies among the students by gender }\end{array}$ & $\begin{array}{l}\text { Mann- } \\
\text { Whitney } U\end{array}$ & $\begin{array}{l}\text { Male } \\
\text { Female }\end{array}$ & $\begin{array}{l}89.38 \\
58.31 \\
\end{array}$ & -4.680 & 0.05 & .000 \\
\hline
\end{tabular}

Note: ${ }^{*}$ statistically significant since $p$-value $<0.05 ;{ }^{* *}$ statistically not significant since $p$-value $>0.05$

As shown above in Table 6, the empirical evidence has supported our research hypothesis that knowledge development varies among the students by gender since the p-value (.000) is less than the significance level (alpha value) of 0.05 . Hence, there is a significant difference among male and female students concerning knowledge development. The empirical evidence has supported the research hypothesis that creating-thinking skill development varies among the students by gender since the pvalue (.000) is less than 0.05. However, the empirical evidence has failed to support the research hypothesis that presentation skill development varies among the students by gender since the p-value (.410) is greater than 0.05 . Hence, it may be said that there is no significant difference among males and females with respect to their presentation skill development. However, our empirical evidence has supported the research hypothesis that punctuality development varies among the students by gender since the p-value (.000) is less than 0.05 .

The empirical evidence has supported the research hypothesis that self-motivational skill development varies among the students by gender since the p-value (.000) is less than 0.05 . Therefore, the study indicated that there is a significant difference between males and females regarding their selfmotivational skill development. The empirical evidence has supported the research hypothesis that language skill development varies among the students by gender since the p-value (.044) is less than 0.05. The empirical evidence has supported the research hypothesis that analytical skill development varies among the students by gender since the p-value (.000) is less than 0.05 . Moreover, empirical evidence has supported the research hypothesis that problem skill development varies among the students by gender since the p-value (.000) is less than 0.05 . Therefore, the study pointed out that personal skill development significantly varies among the students by gender excepting one skill development that is presentation skill development. 
Table 7 is concerned with the research question 3, especially whether social skill development significantly varies among the students by gender. In other words, the Table 7 shows whether there is a significant difference between male and female students pertaining to social skill development. In this connection, the study has tried to validate nine research hypotheses with respect to social skill development by gender as presented below:

Table 7.

Hypotheses testing results summary (social skill development by gender)

\begin{tabular}{|c|c|c|c|c|c|c|c|}
\hline $\begin{array}{l}\text { Item } \\
\text { No. }\end{array}$ & Research hypotheses $\left(\mathrm{H}_{\mathrm{a}}\right)$ & $\begin{array}{l}\text { Statistical } \\
\text { Test }\end{array}$ & $\begin{array}{c}\text { Type of } \\
\text { Respondent }\end{array}$ & $\begin{array}{l}\text { Mean } \\
\text { Rank }\end{array}$ & $\mathrm{Z}$ & $\begin{array}{l}\text { Alpha- } \\
\text { value }\end{array}$ & $\begin{array}{c}p- \\
\text { value }\end{array}$ \\
\hline 1 & $\begin{array}{l}\text { Leadership skill development varies } \\
\text { among the students by gender }\end{array}$ & $\begin{array}{l}\text { Mann- } \\
\text { Whitney } U\end{array}$ & $\begin{array}{l}\text { Male } \\
\text { Female }\end{array}$ & $\begin{array}{l}87.04 \\
61.60\end{array}$ & -3.721 & 0.05 & .000 \\
\hline 2 & $\begin{array}{l}\text { Communication skill development } \\
\text { varies among the students by gender }\end{array}$ & $\begin{array}{l}\text { Mann- } \\
\text { Whitney } U\end{array}$ & $\begin{array}{l}\text { Male } \\
\text { Female }\end{array}$ & $\begin{array}{l}88.93 \\
58.94\end{array}$ & -4.385 & 0.05 & .000 \\
\hline 3 & $\begin{array}{l}\text { Organizing skill development varies } \\
\text { among the students by gender }\end{array}$ & $\begin{array}{l}\text { Mann- } \\
\text { Whitney } U\end{array}$ & $\begin{array}{l}\text { Male } \\
\text { Female }\end{array}$ & $\begin{array}{l}89.74 \\
57.80\end{array}$ & -4.712 & 0.05 & .000 \\
\hline 4 & $\begin{array}{l}\text { Network-building skill varies among } \\
\text { the students by gender* }\end{array}$ & $\begin{array}{l}\text { Mann- } \\
\text { Whitney } U\end{array}$ & $\begin{array}{l}\text { Male } \\
\text { Female }\end{array}$ & $\begin{array}{l}90.77 \\
56.34\end{array}$ & -5.039 & 0.05 & .000 \\
\hline 5 & $\begin{array}{l}\text { Sense of social responsibility varies } \\
\text { among the students by gender* }\end{array}$ & $\begin{array}{l}\text { Mann- } \\
\text { Whitney } U\end{array}$ & $\begin{array}{l}\text { Male } \\
\text { Female }\end{array}$ & $\begin{array}{l}84.01 \\
65.90\end{array}$ & -2.683 & 0.05 & .007 \\
\hline 6 & $\begin{array}{l}\text { Adaptation skill development varies } \\
\text { among the students by gender }\end{array}$ & $\begin{array}{l}\text { Mann- } \\
\text { Whitney } U\end{array}$ & $\begin{array}{l}\text { Male } \\
\text { Female }\end{array}$ & $\begin{array}{l}84.03 \\
65.86\end{array}$ & -2.699 & 0.05 & .007 \\
\hline 7 & $\begin{array}{l}\text { Friendliness skill development varies } \\
\text { among the students by gender* }\end{array}$ & $\begin{array}{l}\text { Mann- } \\
\text { Whitney } U\end{array}$ & $\begin{array}{l}\text { Male } \\
\text { Female }\end{array}$ & $\begin{array}{l}87.70 \\
60.78\end{array}$ & -3.991 & 0.05 & .000 \\
\hline 8 & $\begin{array}{l}\text { Teamwork-building skill } \\
\text { development varies among the } \\
\text { students by gender }\end{array}$ & $\begin{array}{l}\text { Mann- } \\
\text { Whitney } U\end{array}$ & $\begin{array}{l}\text { Male } \\
\text { Female }\end{array}$ & $\begin{array}{l}88.67 \\
59.31\end{array}$ & -3.349 & 0.05 & .000 \\
\hline 9 & $\begin{array}{l}\text { Extroversion development varies } \\
\text { among the students by gender }\end{array}$ & $\begin{array}{l}\text { Mann- } \\
\text { Whitney } U\end{array}$ & $\begin{array}{l}\text { Male } \\
\text { Female }\end{array}$ & $\begin{array}{l}86.92 \\
61.78\end{array}$ & -3.680 & 0.05 & .000 \\
\hline
\end{tabular}

As can be seen from Table 7, the empirical evidence has supported the research hypothesis that leadership skill development varies among the students by gender since the $p$-value (.000) is less than the alpha value of 0.05 . Hence, there is a significant difference between male and female students concerning their leadership skill development. The empirical evidence has supported the research hypothesis that communication skill development varies among the students by gender since the $p$-value (.000) is less than 0.05 . The empirical evidence has supported the research hypothesis that organizing skill development varies among the students by gender since the $p$-value (.000) is less than 0.05 . The empirical evidence has supported the research hypothesis that network-building skill development varies among the students by gender since the $p$-value (.000) is less than 0.05 .

We found statistically significant result with regard to our research hypothesis that the sense of social responsibility development varies among the students by gender since the $p$-value (.007) is less than 0.05 . The empirical evidence has supported the research hypothesis that adaptation skill development varies among the students by gender since the $p$-value (.007) is less than 0.05 . The empirical evidence has supported the research hypothesis that friendliness development varies among the students by gender since the $p$-value (.000) is less than 0.05. Moreover, the empirical evidence has supported the research hypothesis that teamwork-building skill development varies among the students by gender since the $p$ value (.000) is less than 0.05 . Finally, the empirical evidence has supported the research hypothesis that extroversion development varies among the students by gender, as the $p$-value (.000) is less than 0.05 . Therefore, the study put forward that social skill development significantly varies among the students by gender. 
Table 8 shown below is associated with the research question 4 , specifically it illustrates the personal and social barriers to female students' participation in CCAs.

Table 8.

Qualitative interviews about the barriers to female students' participation in CCAs

\begin{tabular}{|c|c|c|c|c|c|c|}
\hline $\begin{array}{l}\text { Respondent's } \\
\text { ID No. }\end{array}$ & Department & Religion & Age & $\begin{array}{c}\text { Wearing } \\
\text { Hijab }\end{array}$ & Respondent's Views & $\begin{array}{c}\text { Personal and Social } \\
\text { Barriers }\end{array}$ \\
\hline 16 & BLWS & Islam & 21 & Yes & $\begin{array}{l}\text { "I like co-curricular activities. } \\
\text { However, I cannot participate } \\
\text { regularly. I wear Hijab and I do } \\
\text { not feel comfortable. My family } \\
\text { does not permit me to get } \\
\text { involved in such activities due to } \\
\text { strong religious values". }\end{array}$ & $\begin{array}{l}\text { - Strong religious } \\
\text { affection } \\
\text { - Don't feel comfortable } \\
\text { - Family restrictions due } \\
\text { to strong religious } \\
\text { values }\end{array}$ \\
\hline 39 & MIS & Islam & 21 & No & $\begin{array}{l}\text { "I have lack of confidence. I am } \\
\text { scared of how people think of } \\
\text { me. My family does not allow } \\
\text { me to participate in co-curricular } \\
\text { activities due to conservative } \\
\text { values. However, I try to } \\
\text { participate occasionally". }\end{array}$ & $\begin{array}{l}\text {-Lack of confidence } \\
\text { - Scared of others' } \\
\text { negative perceptions } \\
\text {-Family restrictions due } \\
\text { to conservative values }\end{array}$ \\
\hline 102 & Sociology & Islam & 20 & Yes & $\begin{array}{l}\text { "I wear Hijab to cover my face } \\
\text { due to my strong religious } \\
\text { attachment. It is difficult for me } \\
\text { to speak publicly and get } \\
\text { involved in co-curricular } \\
\text { activities. Moreover, my family } \\
\text { does not want me to participate } \\
\text { in cultural activities". }\end{array}$ & $\begin{array}{l}\text { - Strong religious } \\
\text { affection } \\
\text { - Difficult to speak } \\
\text { publicly due to veil } \\
\text { - Family restrictions due } \\
\text { to strong religious } \\
\text { attachments }\end{array}$ \\
\hline 116 & ACCE & Islam & 23 & No & $\begin{array}{l}\text { "I like co-curricular activities. } \\
\text { However, I could sometimes } \\
\text { participate. Because, I am afraid } \\
\text { of negative attitudes held by } \\
\text { others towards me. Moreover, } \\
\text { my family is conservative. They } \\
\text { do not always permit me. } \\
\text { However, my brothers have no } \\
\text { restrictions. }\end{array}$ & $\begin{array}{l}\text {-People's negative } \\
\text { attitudes } \\
\text { - Family restrictions } \\
\text { - Conservative family } \\
\text { values }\end{array}$ \\
\hline 148 & THM & Islam & 20 & No & $\begin{array}{l}\text { "My family is conservative. I } \\
\text { cannot always participate in co- } \\
\text { curricular activities due to family } \\
\text { restrictions. Sometimes, when I } \\
\text { fail in such activities, my friends } \\
\text { laugh at me. I don't like this". }\end{array}$ & $\begin{array}{l}\text { - Conservative family } \\
\text { values } \\
\text { - Family restrictions } \\
\text { - Negative attitudes of } \\
\text { friends }\end{array}$ \\
\hline
\end{tabular}

Table 8 shows the qualitative interviews with five Muslim female respondents about the barriers to participate in CCAs. It is evident that the Muslim female respondents face several personal and social problems that usually obstruct them from participating in CCAs. The personal and social barriers involve lack of confidence, lack of comfortableness, negative attitudes of others, and most importantly, the restrictions imposed by their families due to conservative values and deeper religious affections. The personal and social barriers that Muslim female students face to participate in CCAs can be illustrated in the following Figure 2 


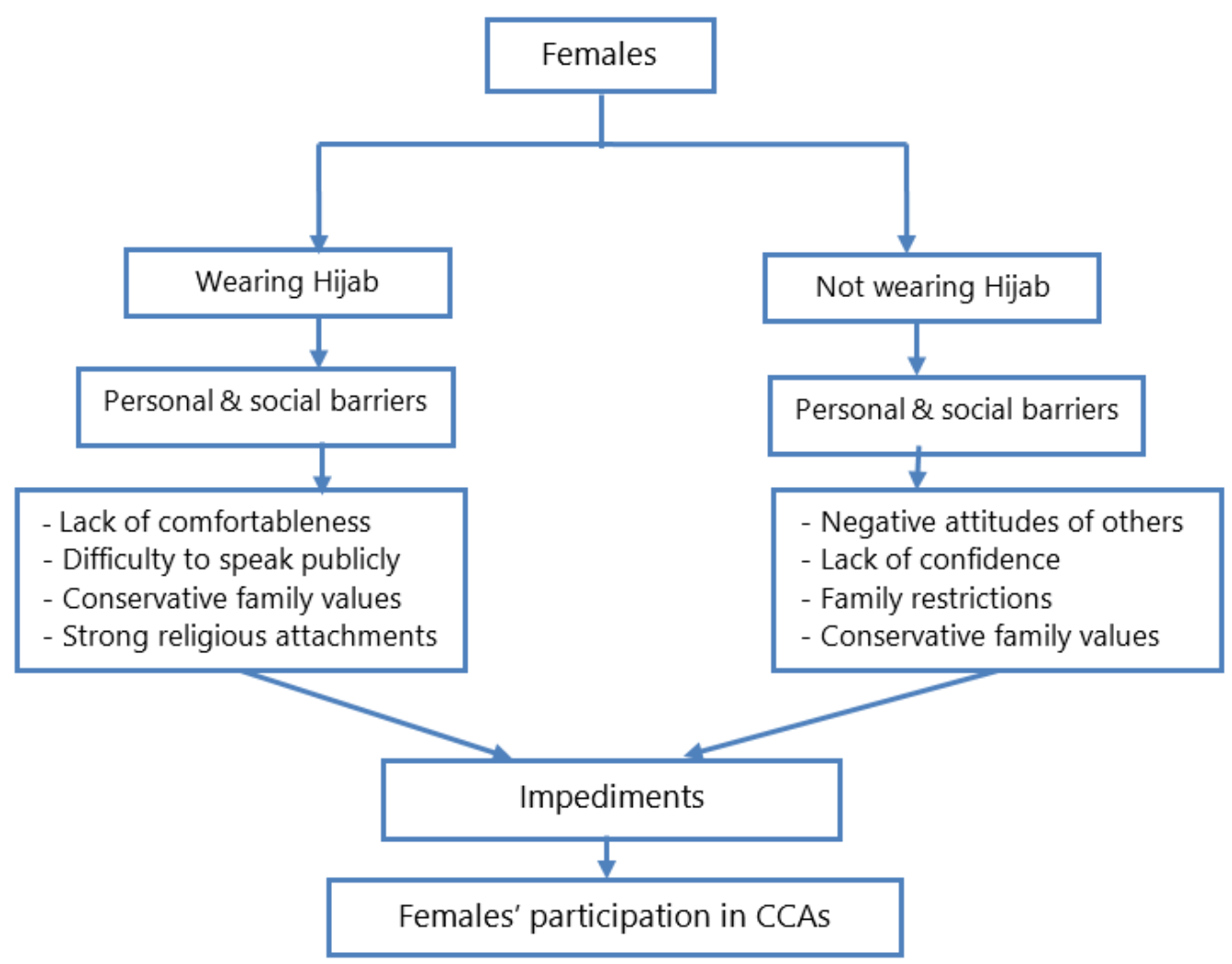

Figure 2. Personal and social barriers of females' participation in CCAs

As shown above in Figure 2, the Muslim female students irrespective of wearing Hijab and not wearing Hijab face a number of personal and social barriers that impede them from participating in CCAs. The students who wear Hijab have been found not to participate in CCAs regularly due to their lack of comfortableness and difficulty to speak publicly on account of their wearing Hijab, conservative family values and deeper religious affections while the students who do not wear Hijab have been found not to participate in CCAs regularly mainly due to the negative attitudes towards them held by others, especially friends, lack of confidence, and family restrictions arising from conservative family values.

\section{DISCUSSION}

The study has shown that soft skill development significantly varies among the students by gender on the whole via their participation in diverse CCAs. However, the study has argued that variation in soft skill development among male and female students may result from their variation in participating in CCAs. The outcomes of the study have been supported by several studies indicating that the more the students participate in CCAs, the more they are likely to develop their personality traits and soft skills (Brandfon, 2018; Ivaniushina \& Zapletina, 2015; Ivanova, et al. 2017; Nghia, 2017; Prianto, 2016). However, their studies have not indicated whether the development of personal skills and social skills, that is, soft skill development significantly varies among the students by gender. While the present study is consistent with the finding put forward by Kumar and Selvaraju (2014) that there is a significant relationship between students' participation in CCAs and their personality development, it negates their finding that there is no significant difference between males and females concerning their personality development on the whole.

Qualitative interviews have suggested that the Muslim female students cannot participate in CCAs regularly due to a number of personal and social barriers involving religious attachments, negative attitudes of others, lack of confidence, and most significantly their family restrictions arising out of conservative family values and strong religious affections which are inherent in the society. In this 
regard, this is to note that now-a-days, wearing Hijab or Veil has been increasingly popular among the Muslim women across the world due to three important reasons: first, it has been a sign of deeper religious affection or Muslim identity; second; ithas been a symbol of fashion and empowerment; and third, it has been a symbol of modesty and privacy (Munir, 2014; Rahman, Islam, \& Ferdousi, 2018; Rita, 2017). The Muslim female students of the NSTU are not an exception.

In this regard, the study has argued that wearing Hijab is very common to the Muslim female students of the NSTU mainly due to their religious affections and family restrictions which may result from conservative family values and deeper religious attachments among the Muslim people of the greater Noakhali region of Bangladesh. The study has indicated that it is difficult for the female students who wear Hijab, especially full-face veil, to speak publicly. The empirical findings have put forward that the students who wear Hijab do not feel comfortable with interacting and communicating with others freely. Moreover, the traditional Muslim families do not allow their females to participate in CCAs, especially in cultural activities. The study has also revealed that the people of our society do not encourage females, compared to males, to participate in CCAs; rather they criticize or hold negative attitudes towards females' participation or performance in such activities. Consequently, they have lack of confidence, lack of motivation, and are scared of what other people think of them.

As such, the study has proposed that although Bangladesh has recently achieved remarkable success in the world in many development parameters, especially in reducing poverty, minimizing gender inequality, and promoting gender development, the females are still disadvantaged group (Bangladesh Bureau of Statistics [BBS], 2017, 2018; United Nations Development Program [UNDP], 2019). BBS (2018) indicated that $67.3 \%$ of the females compared to only $19.5 \%$ of the males are out of labor force. According to BBS (2018), out of 109.1 million working-age population in Bangladesh, 60.8 million (55.8\%) are in employment or engaged in economic activity, of whom only $33.9 \%$ are females (18.7 million). The less participation of females in labor force and employment are attributed to patriarchal gender norms and conservative family roles along with other factors including education (Rahman \& Islam, 2019; Raihan \& Bidisha, 2018). While the society is going through a continuous transformation process, patriarchal gender norms, conservative outlook towards females, and gender-based discriminations are still predominant in Bangladesh and thereby restricting females from participating in diverse development activities (Ahmed \& Sen, 2018; Akter, 2018; Rahman \& Islam, 2019; Raihan \& Bidisha, 2018).

In summary, the study has found that male students have participated regularly in CCAs while female students have participated occasionally in such activities and there is statistically a significant difference between male and female students concerning their participation in CCAs. The study has opined that the degree of personal skill development varies among the students by gender, that is, males have developed personal skills much while females have developed personal skills moderately excepting one skill, presentation skill, which both males and females have developed much. The study has put forward that the degree of social skill development varies among the students by gender, that is, males have developed social skills much while females have developed such skills moderately. The study has shown that personal skill development significantly varies among the students by gender excepting one skill development, that is, presentation skill development, where there is no significant difference between male and female students. The study has revealed that social skill development significantly varies among the students by gender irrespective of all of its dimensions, that is, the males are more likely to develop their social skills than the females. As such, the study has proposed that there is statistically a significant difference between male and female students on the whole concerning soft skill development that involves both - personal skill development and social skill development. The study has argued that the significant difference between male and female students with regard to soft skill development may be attributed to their difference in participating in various CCAs. Since the males are more likely to participate in CCAs, they are more likely to develop their diverse personal skills and social skills, that is, soft skills than the females. 


\section{CONCLUSION and LIMITATIONS}

The development of diverse soft skills among the students via CCAs reinforces the development of their human capacities and diverse personality traits and thereby would facilitate the personality development and employability of the students. Moreover, soft skill development would contribute to the formation of social capital among the students. Nevertheless, the female students are less likely to participate in CCAs. The females are not equally treated with the males. They are not encouraged to take part in such activities; rather they face diverse social and cultural barriers including people's negative attitudes, patriarchal gender norms, and conservative family values which are still widespread in Bangladesh Society. As such, the NGOs and the Government of Bangladesh should undertake proper measures to address the issue. Moreover, Noakhali Science and Technology University should organize a wide range of CCAs regularly to promote soft skill development among the students where special focus should be given to female students in order to encourage their wider participation in such activities. While the study has some key policy implications, it involves two important limitations: first, the samples were collected on the basis of non-probability sampling and hence, sampling procedure could be subject to bias and error; second, the study sought to generalize its findings pertaining to personal and social barriers to females' participation in CCAs based on only five observations. It might reduce the degree of external validity in research. Therefore, the study recognizes the need for undertaking an explanatory research involving both quantitative and qualitative approaches on a larger scale to gain a better understanding of the cultural and social factors that restrict females from increasingly participating in such development activities as CCAs taking into consideration both gender and geographical perspectives.

\section{Acknowledgements}

The paper is the product of my genuine research work conducted in Noakhali Science and Technology University (NSTU) from August, 2019 to October, 2019. I would like to express my sincere thankfulness to the Office of Research Cell, NSTU for considering my research project for allocating research grant. I am thankful to my all colleagues, staff and beloved students for their encouragement throughout my research work. Finally, I am thankful to my six undergraduate students - Rahat, Arif, Hoimi, Emon, Imran and Faiyaz for their sincere efforts and dedications to work with me as data collectors for my research project.

\section{REFERENCES}

Ahmed, T., \& Sen, B. (2018). Conservative outlook, gender norms and family wellbeing: evidence from rural Bangladesh. World Development, 11, 41-58.

Akter, M. (2018). Socio-economic barriers against women equal right in the society: a case of Bangladesh. Open Journal of Social Sciences, 6, 156-166.

Babic, V., \& Slavkovic, M. (2011, June). Soft and hard skills development: A current situation in Serbian companies. Paper presented at the Management, Knowledge and Learning International Conference 2011, International School for Social and Business Studies, Celje, Slovenia.

Bangladesh Bureau of Statistics. (2017). Education scenario in Bangladesh: gender perspective. Dhaka: Author.

Bangladesh Bureau of Statistics. (2018). Labour force survey (LFS) 2018. Dhaka: Author.

Bartkus, K. R., Nemelka, B., Nemelka, M. \& Gardner, P. (2012). Clarifying the meaning of the extracurricular activity: a literature review of definitions. American Journal of Business Education, 5(6), 693-704.

Brandfon, J. (2018). The impact of cocurricular involvement and leadership roles on the perceived development of employability skills (Doctoral dissertation), University of Miami, Florida, USA. Retrieved from, https://pdfs.semanticscholar.org/fd69/f36c57bff85024215717a6e255168390b18e.pdf

Chua, C.J. E., Chuatoco, I.A. G., Dela Pena, A. M.C., Jimenez, D.L.F., \& Co, D. A. (2017). The influence of participation in extracurricular activities to the employability of industrial engineering graduates of one private university in the Philippines. Asia Pacific Journal of Multidisciplinary Research, 5(2), 163-170.

Cimatti, B. (2016). Definition, development, assessment of soft skills and their role for the quality of organizations and enterprises. International Journal for Quality Research, 10(1), 97-130. 
Corder, G.W., \& Foreman, D. I. (2009). Nonparametric statistics for non-statisticians: a step-by-step approach. New Jersey: Wiley.

Cornalli, F. (2018, June 20-22). Training and developing soft skills in higher education [Paper presentation]. The 4th International Conference on Higher Education Advances, Valencia, Spain. DOI: 10.4995/HEAd18.2018.8127

Daniyal, M., Nawaz, T., Hassan, A. \& Mubeen, I. (2012). The effect of co-curricular activities on the academic performances of the students: A case study of the Islamia University of Bahawalpur, Pakistan. Bulgarian Journal of Science and Education Policy, 6(2), 257-272.

Dhanmeher, B. R. (2014). Impact of co-curricular activities on the non-academic development of junior college students (Unpublished master's thesis). DY Patil University, Navi, Mumbai, India.

Educate A Child. (2016). Education and the SDGs. Occasional Paper No. 2. Retrieved from, https://educationaboveall.org/uploads/library/file/2a8e15847d.pdf

Hayes, J. H. (2014). Skill builders: perceived skills enhanced by students through participation in high school extracurricular activities (Published doctoral dissertation). Education and Dissertations Projects, 12. Retrieved from https://pdfs.semanticscholar.org/a786/8c54935299a1a78ab8818ad517d6bf254eed.pdf

Ingale, A. R. (2014). Role of co-curricular activities in student's life. Scholarly Research Journal for Humanity Science \& English Language, 1(4), 592-594.

Ismail, M., Nadeem, M., Hussain, M. H., Shaheen, M. A., Shahid, M., Ahmad, R., \& Mehmood, U. (2016). Role of ECA's (extra-curricular activities) in personality development. International Journal of Research Studies in Biosciences, 4(11), 47-56.

Ivaniushina, V. A., \& Zapletina, O.O. (2015). Participation in extracurricular activities and development of personal and interpersonal skills in adolescents. Journal of Siberian Federal University, 2408-2420.

Ivanova, V., Martins, K., \& Kaftasev, S. (2017). About extra-curricular activities of the university graduatestudent' viewpoint. MATEC Web of Conferences, 91 (2017), 1-4. DOI: 10.1051/matecconf/20179101017

Jamal, A. A. (2012). Developing interpersonal skills and professional behaviors through extracurricular activities participation: A perception of King Abdulaziz University medical students. Journal of King Abdulaziz University: Medical Sciences, 19(4), 3-24.

Kumar, T. R., \& Selvaraju, R. (2014). Personality development through co-curricular activities. Indian Journal of Research, 3(6), 59-61.

Lane, A. (2017). Open education and sustainable development goals: making change happen. Journal of Learning for Development, 4(3), 275-286.

Le, T. (2013). Does participation in extracurricular activities reduces risky behaviour? Youth in Focus. Youth in Focus Project Discussion Paper Series, No. 13, The Australian National University.

Learning Disabilities Association of Canada. (n.d.) What are social skills? Ottawa. Retrieved from https://www.ldabc.ca/wp-content/uploads/2012/08/English-Social-Emotional.pdf

Leung, C., Ng, C. W. R., \& Chan, P. (2011). Can co-curricular activities enhance the learning effectiveness of students? An application to the sub-degree students in Hong Kong. International Journal of Teaching and Learning in Higher Education, 23(3), 329-341.

Lunenburg, F. C. (2010). Extracurricular activities. Schooling, 1(1), 1-4. Retrieved from, http://www.nationalforum.com/Electronic\%20Journal\%20Volumes/Lunenburg,\%20Fred\%20C\%20Extra curricular\%20Activities\%20Schooling\%20V1\%20N1\%202010.pdf

Mehmood, T., Hussain, T., Khalid, M., \& Azam, R. (2012). Impact of co-curricular activities on personality development of secondary school students. International Journal of Humanities and Social Welfare, 2(18), 139-145.

Munir, E. T. (2014). The dynamics of wearing hijab for Muslim American Women in the United States (Published master's thesis). Iowa State University, Iowa, USA.

Nachmias, F. C., \& Nachmias, D. (2008). Research methods in the social sciences. New York: Worth Publishers.

National Association of School Psychologists. (2002). Social skills: Promoting positive behavior, academic success, and school safety. Maryland, USA. Retrieved from, http://mendocinousd.org/view/81.pdf

Nghia, T. (2017). Developing generic skills for students via extra-curricular activities in Vietnamese universities: Practices and influential factors. Journal of Teaching and Learning for Graduate Employability, 8(1), 2239.

Patacsil, F. E. P., \&Tablatin, C.L. S. (2017). Exploring the importance of soft and hard skills as perceived by it internship students and industry. Journal of Technology and Science Education, 7(3), 347-368.

Prianto, A. (2016). The effect of the involvement intensity in extracurricular activities and soft skills towards readiness to work for higher education graduates in East Java Indonesia. The Journal of Business and Management Invention, 5(6), 79-87.

Rahman, S.M., Islam, M.N., \& Ferdousi, A. (2018). Is hijab a fashion statement? A study on Bangladeshi Muslim women. IOSR Journal of Business and Management, 20 (12), 21-27. 
Rahman, R., \& Islam, R. (2019). Employment, labour force participation and education: towards gender equality in Bangladesh. Dhaka: Centre for Development and Employment Research.

Raihan, S. \& Bidisha, S.H. (2018). Female employment stagnation in Bangladesh. A research paper on Economic Dialogue on Inclusive Growth in Bangladesh. Retrieved from https://asiafoundation.org/wpcontent/uploads/2018/12/EDIG-Female-employment-stagnation-in-Bangladesh_report.pdf

Rita, A. A. (2017). Assertion of wearing hijab in the community: An analysis. American Scientific Research Journal of Engineering, Technology and Sciences, 29(1), 340-347.

Siddiky, M. R. (2019). Developing co-curricular activities and extra-curricular activities for all-round development of the undergraduate students: A study of a selected public university in Bangladesh. Pakistan Journal of Applied Social Sciences, 10, 61-82.

Singh, A., \& Mishra, S. (2015). Extracurricular activities and student's performance in secondary school of government and private schools. International Journal of Sociology and Anthropology Research, 1(1), 5361.

Taber, K.S. (2017). The use of Cronbach's alpha when developing and reporting research instruments in science education. Research in Science Education, 48, 1273-1296. DOI: 10.1007/s11165-016-9602-2

United Nations Educational, Scientific and Cultural Organisation. (2017a). Education for sustainable goals: learning objectives. Paris: Author. Retrieved from http://unesdoc.unesco.org/images/0024/002474/247444e.pdf

United Nations Educational, Scientific and Cultural Organisation. (2017b). Unpacking sustainable development goal 4. Paris: Author. Retrieved from http://unesdoc.unesco.org/images/0024/002463/246300E.pdf

United Nations Development Program. (2019). Human Development Report 2019. Beyond income, beyond averages, and beyond today: Inequalities in human development in $21^{\text {st }}$ centuries, New York: Author.

Villalobos, A. S., Dulce, A.C., Fontilar, L.J., Gutierrez, D.C., Sawali, R.C., \& Almero-Encio, H. (2016). Benefits of co-curricular activities to academic performance of financial and management accounting students. Asia Pacific Journal of Arts and Sciences, 3(1), 83-93. 